\title{
Herpetofauna and roads: a review
}

\author{
Víctor J. Colino-Rabanal", Miguel Lizana \\ Area of Zoology, Department of Animal Biology, Ecology, Soil Science, Parasitology, and Agrochemistry, University of Salamanca, \\ Salamanca, Spain \\ * Correspondence: Department of Animal Biology, Ecology, Soil Science, Parasitology, and Agrochemistry, Campus Miguel de \\ Unamuno 37071 Salamanca, Spain. E-mail: vcolino@usal.es
}

Received: 14 October 2012; received in revised form: 4 December 2012; accepted: 18 December 2012.

Roads and traffic are tightly related to some of the mains threats for biodiversity. Road network affects wildlife populations due to, among other effects, partial occupation and transformation of landscape, alteration of surrounding habitat, dispersal of physicochemical pollutants, fragmentation and loss of connectivity, or direct road-kills. Because of their ecological characteristics, amphibians and reptiles are very exposed to road effects. In this article we review the relationship between these faunal groups and the road network. Amphibians exhibit high road-kill rates that can condition viability of some populations, and are vulnerable to pollution of road margins. Reptiles also suffer casualties because of road-kills when they move to paved roads for thermoregulation. Roads, especially those with high traffic load, act as barriers that difficult movements and contribute to population isolation in both groups. However, road impacts do not have equal intensity over space and time, and consequently some spatio-temporal patterns can be defined. Not all species show the same degree of exposure to road impacts, which depend on specific ecological requirements in each case. Mobile species are generally more vulnerable than sedentary ones. There are also intra-specific differences as a function of gender and age. All these considerations must be taken into account when designing and implementing the corresponding mitigation measures necessary to reduce the negative effects of roads on herpetofauna populations.

Key words: fragmentation; mitigation measures; road ecology; road-effect zone; road-kills; road pollution.

Herpetofauna y carreteras: revisión. Las carreteras y el tráfico rodado están estrechamente relacionados con varias de las principales amenazas para la biodiversidad. La red viaria impacta en las poblaciones de fauna silvestre, entre otros, mediante la ocupación y transformación de parte del territorio, la alteración del hábitat circundante, la dispersión de contaminantes físico-químicos, la fragmentación y pérdida de conectividad, o la mortalidad directa por atropello. Debido a sus características ecológicas, tanto los anfibios como los reptiles presentan una gran exposición a los efectos de las carreteras. En este artículo hacemos una revisión de la relación entre estos grupos faunísticos y la red viaria. Los anfibios experimentan elevadas tasas de atropello que pueden condicionar la viabilidad de algunas poblaciones y son vulnerables a la contaminación ligada a los márgenes de las carreteras. Los reptiles también sufren bajas por atropello al acudir a la calzada a termorregular. Para ambos grupos, las carreteras, sobre todo las de alta capacidad, constituyen barreras que dificultan sus movimientos y aíslan sus poblaciones. Sin embargo, los impactos no revisten la misma intensidad ni en el espacio ni en el tiempo, siendo posible definir una serie de patrones espacio-temporales. No todas las especies presentan el mismo grado de exposición a los impactos de las carreteras sino que éste depende de los requerimientos ecológicos específicos de cada una de ellas. En general, las especies más móviles son las más vulnerables. También hay diferencias intraespecíficas en función del sexo y la edad. Todas estas consideraciones deben ser tenidas en cuenta a la hora de diseñar e implementar las medidas de mitigación correspondientes para tratar de reducir los efectos negativos de las carreteras sobre las poblaciones de herpetofauna.

Key words: atropellos; contaminación; ecología de carreteras; fragmentación; medidas de mitigación; zona efectiva de la carretera. 
The increment of both transport networks and social concern about environmental issues has led to an increase in the interest for studying the relationships between wildlife and roads. This has attracted the attention of many researchers, resulting in the emergence of a new discipline known as road ecology, whose main goal is the study of the interactions between organisms and the environment linked to road networks and traffic (Forman et al., 2003). Roads impact wildlife by means of causing habitat loss, population fragmentation, direct mortality, changes in animal behaviour, physical and chemical alterations of the environment, and dispersal of exotic species (MALO et al., 2004; JAARSMA et al., 2006; FAHRIG \& RYTWINSKY, 2009). Furthermore, the construction of new roads facilitates the use and modification of adjacent habitats by humans (Forman \& Alexander, 1998; TrombulaK \& FRISSELL, 2000), which indirectly contributes to additional impacts on wildlife.

Amphibians and reptiles show certain ecological characteristics that make them highly vulnerable to roads impacts. For example, they show a low vagility in comparison to other vertebrates, being especially susceptible to habitat fragmentation by linear infrastructures. Moreover, in reptiles, roads constitute an important heat source for thermoregulation. In the case of amphibians, many species show complex life cycles, usually involving periodical migrations among the various complementing habitats in order to complete their annual cycle. Mortality rates during migrations associated with direct road-kills are in some cases high enough to cause effects at the population level. Moreover, their permeable skin, with osmoregulatory and respiratory functions, makes them sensitive to road pollution. These direct and indirect effects of roads are among the main causes contributing to the global amphibian decline (BlaUstein \& WaKE, 1990; HOULAHAN et al., 2000; COLLINS \& STORFER, 2003; NysTRÖM et al., 2007). In this review, we summarize the progress made in the study of the effects of roads on the herpetofauna at multiple scales. Furthermore, we also analyse the mitigation measures proposed to reduce these road impacts.

\section{HERPETOFAUNA IN ROAD MORTALITY STUdies}

The first studies in road ecology at the beginning of the $20^{\text {th }}$ century alerted about the direct mortality of wildlife caused by vehicles on roads. The first specific studies about herpetofauna focused mostly on snake mortality (BugBeE, 1945; FITCH, 1949; CAMPBELl, 1956), but also on amphibians (CARPenter \& Delzell, 1951). Hodson (1960) made regular counts in a $3.2 \mathrm{~km}$ road stretch near Northamptonshire (England) and found 683 vertebrates of 42 species killed on the road. The species with the highest mortality rate was the European common frog (Rana temporaria) with 191 casualties.

Most of the studies have been carried out in Europe (e.g. Belgium: BaLlasinA, 1989; Germany: PODLOUCKY, 1989; the Netherlands: ZUIDERWIJK, 1989; Switzerland: RYSER \& GROSSENBACHER, 1989; Portugal: Brito \& Álvares, 2004; France: LESBARRÈRES et al., 2006, Poland: BRZEZIŃSKI et al., 2012), North America (PALIS, 1994; Ashley \& Robinson, 1996; RAY et al., 2006) and Australia (SEABRoOK \& DetTMAN, 1996; Hoskin \& Goosem, 2010), but in recent times, new studies have been conducted in South America (CAIRO \& ZALBA, 2007; 
HARTMANN et al., 2011; COELHO et al., 2012; QUINTERO-ÁNGEL et al., 2012) and Asia (SESHADRI et al., 2009; ZHANG et al., 2010; GU et al., 2011; TOK et al., 2011).

If the herpetofauna is especially vulnerable to road effects, road surveys will be expected to obtain a high rate of casualties in comparison to other vertebrate groups. Table 1 shows the results of several studies that have quantified road mortality for all vertebrate groups in different countries, and herpetofauna, especially amphibians, appears in most cases as the group with the highest road-kill rates. The percentage distribution among the different groups varies both with the type of landscape present in the study area and the methodology followed in the road surveys. Thus, in some cases the number of amphibian and reptile casualties is low due to the low suitability of the prospected areas for these groups, or because the census technique underestimates the real number of casualties of these small-sized animals (MONTORI et al., 2003). Nevertheless, GrYZ \& KRAUZE (2008) found in a two-year monitoring study of a local road across Poland's Biebrza River Valley that $90.7 \%$ of all the reported casualties were amphibians, especially anurans like the common toad (Bufo bufo), the moor frog (Rana

Table 1: Percentage of amphibian and reptile casualties in road surveys aimed to study road mortality for all vertebrate groups. Specific surveys for a certain group were not included in the table.

\begin{tabular}{|c|c|c|c|c|c|}
\hline Study & $\begin{array}{l}\text { Amphibians } \\
(\%)\end{array}$ & $\begin{array}{c}\text { Reptiles } \\
(\%)\end{array}$ & Survey methodology & $\begin{array}{l}\text { Location and landscape } \\
\text { description }\end{array}$ & $\begin{array}{l}\text { Traffic volume } \\
\text { (vehicles/day) }\end{array}$ \\
\hline $\begin{array}{l}\text { GONZÁLEZ-PRIETO et al. } \\
\text { (1993) }\end{array}$ & 89.2 & 5.0 & Walking. Weekly surveys. & $\begin{array}{l}\text { Road stretch parallel to Miño River, Ourense } \\
\text { (Spain). Oak forest with some eucalyptus } \\
\text { and pine spots, cultivated areas, scru- } \\
\text { blands and sub-urban habitat. }\end{array}$ & $\mathrm{n} / \mathrm{a}$ \\
\hline $\begin{array}{l}\text { ASHLEY \& ROBINSON } \\
\text { (1996) }\end{array}$ & 93.8 & 2.7 & $\begin{array}{l}\text { Walking and bicycling. Three times } \\
\text { per week during spring-summer. }\end{array}$ & $\begin{array}{l}\text { Wetlands in the Long Point Causeway, } \\
\text { Lake Erie (Canada). }\end{array}$ & -3000 \\
\hline CleVENGER (1999) & 23.3 & - & $\begin{array}{l}\text { Vehicle and walking. Methodologies } \\
\text { adapted to different specimen sizes. }\end{array}$ & $\begin{array}{l}\text { Bow River Valley, along the Trans-Canada } \\
\text { highway corridor in Banff National Park. }\end{array}$ & $>14000$ \\
\hline LODÉ (2000) & 29.2 & 1.1 & Vehicle. & Department of Vendée (France). & 19320 \\
\hline CleVENGER et al. (2003) & 7.1 & & Vehicle. From April to November. & Central Rocky Mountains (Canada). & -14000 \\
\hline $\begin{array}{l}\text { TAYLOR \& GOLDINGAY } \\
(2004)\end{array}$ & 0.4 & 5.9 & Vehicle. & $\begin{array}{l}\text { New South Wales (Australia). Coastal } \\
\text { lowlands and volcanic plateau. Open pastures, } \\
\text { eucalypt forest, plantations, scattered } \\
\text { areas of rainforest. }\end{array}$ & $5000-20000$ \\
\hline $\begin{array}{l}\text { DÁVILA BLANES et al. } \\
\text { (2007) }\end{array}$ & 9.0 & 48.0 & Vehicle. Daily surveys. & $\begin{array}{l}\text { Road of access to Carrascal de la Font Roja } \\
\text { Natural Park (SE Spain). }\end{array}$ & $\mathrm{n} / \mathrm{a}$ \\
\hline GLISTA et al. (2008) & 93.3 & 1.3 & Vehicle. Twice per week. & $\begin{array}{l}\text { Indiana (USA). Wetlands and ditches su- } \\
\text { rrounded by agricultural lands and hardwood. }\end{array}$ & $1900-6300$ \\
\hline GRYZ \& KraUZE (2008) & 90.7 & 2.0 & Walking. 3-7 days per month. & $\begin{array}{l}\text { Biebrza River Valley (Poland). River, oxbow } \\
\text { lakes, meadows and flooded pastures. }\end{array}$ & -850 \\
\hline $\begin{array}{l}\text { HOBDAY \& MINSTRELL } \\
(2008)\end{array}$ & - & 0.8 & $\begin{array}{l}\text { Vehicle. Five regions, one survey } \\
\text { per season. }\end{array}$ & $\begin{array}{l}\text { Tasmania (Australia). Native and regenerated } \\
\text { forest, woodland, grasslands and farming } \\
\text { regions. }\end{array}$ & $\mathrm{n} / \mathrm{a}$ \\
\hline GEROW et al. (2010) & 41.5 & 41.7 & Vehicle and walking. Once per week. & $\begin{array}{l}\text { Saguaro National Park in south-eastern } \\
\text { Arizona (USA). }\end{array}$ & $2200-6000$ \\
\hline $\begin{array}{l}\text { CARVALHO \& MirA } \\
(2011)\end{array}$ & $24.1-66.1$ & $4.4-6.5$ & Vehicle. Every two weeks. & $\begin{array}{l}\text { Mediterranean agro-silvo-pastoral system } \\
\text { (Portugal). }\end{array}$ & $3000-7000$ \\
\hline $\begin{array}{l}\text { GARRIGA et al. } \\
\text { (2012) }\end{array}$ & 62.0 & 12.2 & $\begin{array}{l}\text { Vehicle. Three times in spring } \\
\text { and three times in autumn. }\end{array}$ & Road stretches across Catalonia (Spain). & $126-10466$ \\
\hline
\end{tabular}


arvalis) and other Rana spp. that were killed during their migration to the breeding ponds. GLISTA et al. (2008) reported a percentage of amphibians even higher (95\%) for four road surveys conducted in Indiana, USA.

Unfortunately, despite these evidences, there are not too many studies addressing long-term trends in herpetofauna road-kills. The direction of these trends is difficult to foresee and may vary among areas. In some parts, road-kills have increased in recent decades in line with the road network expansion and the increasing number of vehicles and displacements (CARvalHo \& Mira, 2011). On the other hand, road-kills in other areas have decreased as a consequence of parallel population declines associated with the own road impacts (BROCKIE et al., 2009). Considerable variations among years are common due to population fluctuations related to environmental conditions or stochastic phenomena (COOKE, 1995). Thus, long-term studies are needed to detect accurate trends.

As mentioned above, amphibian road-kills can reach very high rates. GOLDINGAY \& TAYLOR (2006) estimated a mortality of more than 40000 frogs per year in a $4-\mathrm{km}$ stretch road in north-eastern New South Wales, Australia. Among reptiles, snakes are also commonly killed on roads due to their use as thermoregulation sites (ROSEN \& LOWE, 1994). Freshwater turtles are another of the most vulnerable reptile groups to road mortality (GOODMAN et al., 1994; HAXTON, 2000). Data about lizard road-kills are scarce, but this group does not usually seem to suffer an elevated rate of road mortality; for example, in a study about the impact of off-highway recreation in southern California desert lands, GRANT \& DOHERTY (2009) found no direct mortality of the flat-tailed horned lizard (Phrynosoma mcallii) caused by off-road vehicles, although they caused other disturbances and indirect impacts that reduced habitat quality for the species. However, some saurian species can reach high road-kill rates on a local scale. In a road near Barcelona (Spain), the common wall gecko (Tarentola mauritanica) accounted for $20.2 \%$ of all herpetofauna road-kills, being the second most killed species (MONTORI et al., 2003). Nevertheless, the comparison of road mortality rates among all these studies is very complex and the results are difficult to interpret due to differences in study areas, population abundance, species richness, types of road, traffic densities, and species surveyed (ЈАКОВ et al., 2003; PinOwSKI, 2005; GLista et al., 2008; SiLlERO, 2008; ELZANOWSKI et al., 2009).

Just as with other issues in conservation, social perception of wildlife road-kills varies in relation to species size. In general little public awareness is given to small size faunal groups such as amphibians and reptiles. However, they are suffering numerous casualties on the roads that can compromise population viability at a local scale (LANGTON, 1989; FAHRIG et al., 1995). This situation is even more puzzling considering that the implementation of effective solutions would be economically viable, at least for the main hotspots of herpetofauna road-kills.

\section{METHODOLOGIES TO STUDY ROAD MORTALITY}

Road mortality is generally recorded by direct counting of both dead and alive specimens on roads (VAN GELDER, 1973). However, when detecting all casualties by counting is 
not viable because, for example, a high extension of territory is aimed to be covered, a combination of counting and road fencing can be used (GIBBS \& SHRIVER, 2005). In these cases there is always a discrepancy between the actual and the quantified numbers. Apart from species' anatomical and ecological characteristics, detection probability varies with the number of surveys, methodology used, and experience and skills of the staff involved in the census. Other important factors to take into account are the presence of scavengers that can remove the corpses, the topography and type of vegetation on the edges of the road, the weather and the time of the day (ANTWORTH et al., 2005). Thus, it is estimated that the actual number of road-kills can be up to 12-16 times higher than the estimated by a daily census (SLATER, 2002).

Amphibian carcasses remain just a few hours on the road (SANTOS et al., 2011). Given that most road-kills occur at night, many carcasses may have disappeared in the morning, especially in roads with elevated traffic volumes. Furthermore, because of their small size and their fragility they are difficult to detect. Some species like the common fire salamander (Salamandra salamandra) may remain for longer on the road due to their tough skin and unpalatability (SANTOS et al., 2011). The season is also important to get accurate estimations; for example, to adequately study the road mortality problem on amphibian populations, sampling should be conducted preferably during migration days.

The method of sampling depends on the goals of the study. Quantifying mortality and assessing potential population consequences require a method that allows the detection of as many individuals as possible so that the closer we get to the real number, the better. These studies require walking surveys because during vehicle surveys many corpses remain undetected, and detection probabilities vary with the species. Some herpetofaunal studies consider that the maximum vehicle speed allowing for detection of all road-killed specimens is $20 \mathrm{~km} / \mathrm{h}$ (SANTOS et al., 2007). However, if the aim is to locate hotspots where mitigation measures have to be implemented, both walking and vehicle surveys are valid. While walking surveys increase detection probabilities, vehicle surveys allow covering greater distances in less time, which is important considering the short time of residence of the corpses on the road (LANGEN et al., 2007).

\section{RoAD-KILl SPaTio-Temporal DISTRIBUTION}

Herpetofauna road-kills are not randomly distributed in either space or time, but are concentrated in certain road segments during certain periods of time throughout the year. As amphibians and reptiles perform relatively localized displacements, it is possible to identify the variables that explain the spatial distribution of the hotspots, as well as the places where priority to the installation of mitigation measures should be given. The availability of suitable habitats (closeness to ponds and rivers, natural vegetation, absence of anthropogenic disturbance) is a factor commonly identified in road-kill spatial models (Sillero, 2008). LANGEN et al. (2009) found that, for amphibian and reptile species in the north of New York State, road-mortality hotspots were located within a distance of $100 \mathrm{~m}$ from a wetland, especially in elevated road sections that presented wetlands on both 
sides. SANTOS et al. (2007), working in the road network of Catalonia (NE Spain), identified the presence of streams crossing the road, little steep roadsides, and semi-natural vegetation as the main explanatory factors of B. bufo road-kill locations. ORŁOWSKI et al. (2008) found that the proportion of habitat occupied by forests and the presence of ponds were the main determinants of the distribution of amphibian road-kills in south-western Poland. Not only the presence but also the size of water bodies in the road vicinity was also relevant (ORŁOWSKI, 2007). In other cases, wet grasslands instead of forest are the landscape types most associated with amphibian road-kills (Gu et al., 2011). For freshwater turtles in New York State, hotspots were located at causeways that were larger than $200 \mathrm{~m}$ length, in close proximity to water, and with high forest coverage (LANGEN et al., 2012). It is important to take into account that the spatial distribution of road-kills is correlated with species local abundance (ORŁOWSKI, 2007), which in turn depends on habitat features and varies throughout the year and among years.

Apart from landscape variables, road parameters are also important to locate herpetofauna road-kills. For example, the probability of crossing highways is practically null (HELS \& BuCHWALD, 2001, but see CARRETERO \& ROSELL, 2000). Also, road-kill rate can be lower in main roads than in secondary ones, which could be explained by the previous population decline caused by roads with high traffic intensity (ORŁOWSKI, 2007). In general terms, it is supposed that the number of roadkills increases with traffic volume. Due to their small sizes and relatively low speed of movements, amphibians and reptiles suffer high number of casualties even with very low traffic volumes. Thus, van GELDER (1973) estimated that a traffic frequency of 10 vehicles per hour caused the loss of $30 \%$ B. bufo females that tried to cross the road to and from a breeding pond in the Netherlands. Furthermore, roads with low traffic volume can be more attractive for basking and feeding, as demonstrated by LEBBORONI \& CORTI (2006) in lizards from central Italy, thus involving a higher risk of road-kill than roads with high traffic density. Nevertheless, the relationship between road-kills and traffic volumes varies with the species considered. MAZEROLle (2004a) found that increased traffic intensities elevated the number of casualties in the American toad (Anaxyrus americanus) but decreased it in the spring peeper (Pseudacris crucifer). For frogs of the genus Lithobates the maximum number of road-kills was obtained at medium traffic volumes. For a given species, it is possible to calculate the probability of an individual being road-killed by considering the speed, the angle of intersection, and the traffic intensity. However, as explained below, some animals show specific behaviours in relation to traffic that reduce accuracy of this kind of estimates.

At regional scale, habitat variables are better indicators to define areas with high road mortality rates than traffic volume, since they determine local distribution of the species (ORŁOWSKI et al., 2008). For this reason, it is essential to understand the different spatial scales at which threat processes operate. In this sense, road segment and population scales are more suitable than regional and species distribution scales to identify the best location for implementation of the mitigation measures (BEAUDRY et al., 2008). 
The temporal distribution of herpetofauna road-kills is related to species' activity patterns (BERNARDINO \& DALRYMPLE, 1992; BONNET et al., 1999). Inter-specific differences can also be partially explained by differences in species' ecological requirements. For amphibians, high risk exists during breeding migrations, which show high inter-specific variation in terms of distance (MONTORI et al., 2003; KOVAR et al., 2009). In the Lozoya Valley (Madrid, Spain) the peaks of road mortality for the natterjack toad (Bufo calamita) and B. bufo occurred between the last two weeks of March and the first two weeks of May, during the seasonal migrations to the breeding sites (SCV, 2003). As migration distances increase, the probability of crossing roads also increases. Moreover, the breeding habitat requirements condition roadkill locations. Thus, species that can breed in any accumulation of shallow water will have less defined hotspots than those species that breed in ponds or streams.

In turtles and snakes, breeding season also concentrates most road-kills (BONNET et al., 1999; Cureton \& Deaton, 2012). Furthermore, daily variations in temperature and precipitation may also influence road mortality rates, as observed by SHEPARD et al. (2008a) in these two groups of reptiles, whose frequency of road-kills is positively correlated with minimum daily temperatures.

The behaviour in response to roads and traffic is another important factor determining the spatio-temporal distribution of road-kills, not only at the inter-specific but also at the intra-specific level. Many individuals remain immobile when sensing the arrival of a vehicle, which involves an increase in the crossing time, and consequently in the probability of being killed (MAZEROLLE $e t$ al., 2005). For example, northern leopard frogs (Lithobates pipiens) move at a slower speed and following more tortuous paths as they approach roads. Furthermore, movement speed is also reduced as traffic volume grows, two synergistic factors that reduce the probability of cross success in this species (BOUCHARD et al., 2009).

In the case of snakes and other reptiles as the snapping turtle (Chelydra serpentina), the number of road-kills increases as a consequence of the intentional action of the drivers. In a study conducted in Canada, up to $2.5 \%$ of the drivers positively selected to hit reptiles (AsHLey et al., 2007). In other Australian study, $25 \%$ of drivers reported that they intentionally ran over invasive cane toads (Rhinella marina). However, field experiments did not confirm this behaviour, but found a rate of collisions not different from random (BECKMANN \& SHINe, 2012).

\section{IMPACTS OF ROADS ON HERPETOFAUNA}

\section{The effects of road pollution}

The impact of the emission of pollutants by vehicles and the use of certain chemicals in road maintenance (herbicides, de-icing salts) on herpetofauna (Fig. 1) has been studied almost exclusively in amphibians, and most examples point to a negative effects on their populations. For example, the proximity to the road correlates with an increased probability of suffering skeletal malformations and a smaller body size in larval wood frogs (Lithobates sylvaticus) (REEves et al., 2008). Although the causes are not entirely clear, an increased risk of injury caused by predation due to a small size, a change in the composi- 


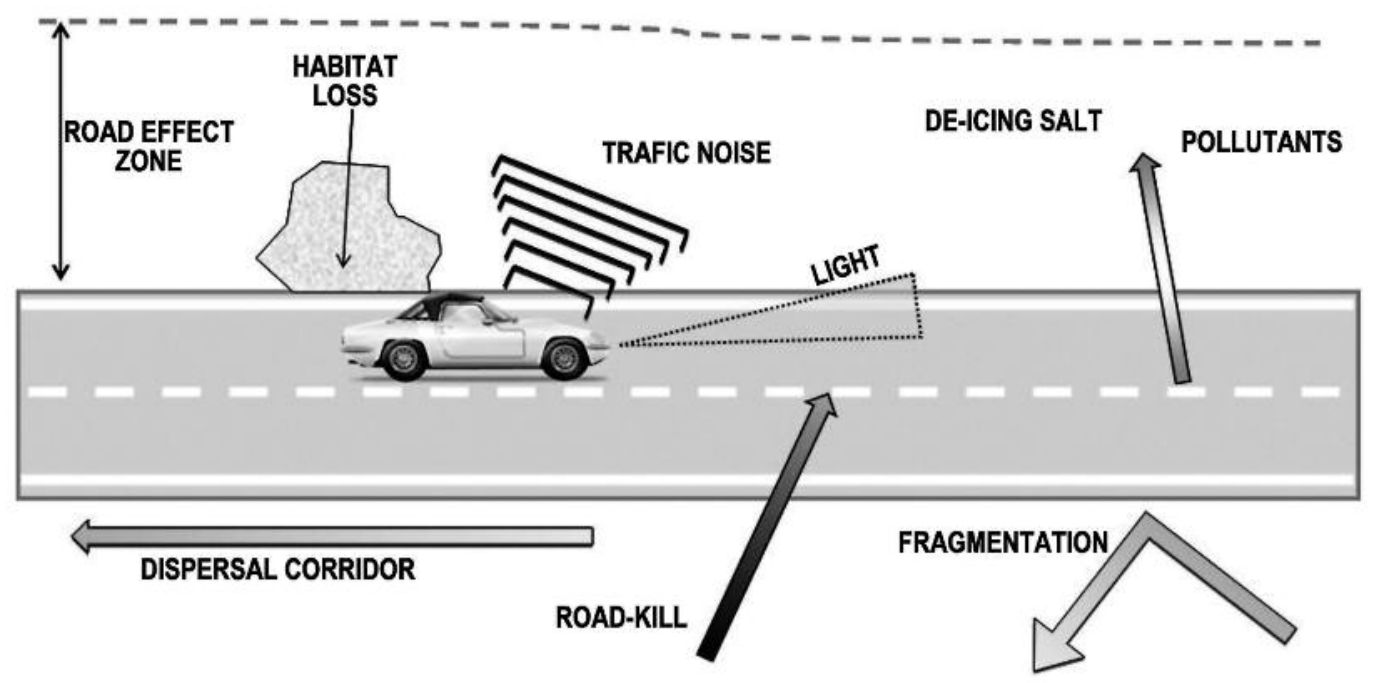

Figure 1: Main road effects on herpetofauna populations. Construction of new roads can imply the loss of high quality habitats for herpetofauna. Moreover, amphibians and reptiles can be road-killed when trying to cross. Roads difficult their movements by increasing fragmentation and exerting a barrier effect; however, road ditches sometimes act as corridors. Traffic flow also impacts on populations through dispersal of chemical pollutants or other types of pollution as noise or lighting. Some practices like the use of de-icing salt in winter maintenance can also impact amphibian or reptile populations. All these road impacts extend tens or hundreds of meters away from the road edge delimiting the road-effect zone.

tion of predator community, or the presence of chemical contaminants from vehicle traffic could explain this phenomenon (REEVES et al., 2008). Also, amphibian larvae near roads with high traffic volume bioaccumulate lead from fossil fuels at doses that may have physiological and reproductive effects (Birdsall et al., 1986). However, this problem has been reduced after removal of this heavy metal from fuels.

A widely extended maintenance practice is the use of de-icing salt to prevent the formation of ice and snow on the road. This affects large regions at high latitudes and mountainous areas where frost and snow precipitation are common during winter. Winds or the water runoff can carry salt tens to hundreds of meters away from the roadside, increasing salinity in rivers and ponds nearby. High concen- trations of salt in the water act as an environmental stressor affecting aquatic fauna with low tolerance to salinity. On amphibians, high salt concentrations can induce death by dehydration. Increased water salinity in road surroundings produced a reduction in survival rate, metamorphosis time, activity, and weight, as well as an increase in the number of malformations in larval L. sylvaticus (SANZO \& HeCNAR, 2006). For this species and for the spotted salamander (Ambystoma maculatum), KARRAKER et al. (2008) also found a reduction in the survival rate of embryos and larvae along with an up to $50 \%$ decrease in the number of egg masses in the vicinity of roads. They concluded that these effects could lead to local extinctions, especially of $A$. maculatum populations, given its high sensitivity to salinity. Laboratory experiments conducted in micro- 
cosms with water collected from basins receiving runoff from high-capacity roads showed total mortality of exposed L. sylvaticus larvae, while $A$. americanus larvae did not suffer lethal effects (SNODGRASS et al., 2008). In this sense, because of the inter-specific differences in sensitivity, the salt used on roads could act as a stressor capable of changing the structure of amphibian communities (Collins \& RuSSELL, 2009).

\section{The impact of traffic noise and light}

High levels of environmental noise caused by traffic pose a great challenge for species that use acoustic communications (Fig. 1). Thus, traffic noise reduces the ability of female Cope's gray treefrogs (Hyla chrysoscelis) to detect male calls (BEE \& SwANSON, 2007). In an attempt to avoid masking by high levels of environmental background sound, terrestrial animals can introduce changes in the features of their acoustic signals. This capacity could be a key factor for reproductive success in noisy environments. In amphibians, some well-documented cases for this phenomenon show that the increases in signal frequencies in order to avoid masking (i.e. whistling tree frog, Litoria ewingii) are less marked than those identified for birds, but also sufficient to improve communication capacity (PARRIS et al., 2009). Another species, the Neotropical treefrog (Dendropsophus triangulum), is capable to increase its song rate (KAISER \& HAMMERS, 2009). In an experiment exposing anurans inhabiting far away from roads to traffic noise recordings, CUNNINGTON \& FAHRIG (2010) showed that animals immediately altered their vocalization characteristics in a similar way as indivi- duals living permanently in locations with high traffic noise. This plasticity is essential to maintain acoustic communication in environments with traffic noise. However, LENGAGNE (2008) did not detect the ability to modify the frequencies or temporal structure of the call in the European tree frog (Hyla arborea), which suggests that those species capable to acclimatize to traffic noise may have a competitive advantage respect to less plastic species. In this regard, SUN \& NARINS (2005) found that in a community exposed to environmental noise, individuals of the two-striped grass frog (Hylarana taipehensis) took advantage of this factor by increasing its song rate while the other three studies species decreased it.

Light is another element associated with roads and traffic that may impact herpetofaunal populations. As many species are nocturnal, car lights may lessen their ability to prevent being killed by vehicles, since such lights saturate their retinas leaving them blind and disoriented for a few seconds. Light pollution also affects the ability of some species to detect and capture prey (BUCHANAN, 1993).

\section{Habitat fragmentation and loss of connectivity}

Roads act as barriers and/or filters, causing habitat fragmentation and population isolation (Fig. 1). Fragmentation is among the largest threats for amphibian and reptile populations (BECKER et al., 2007). Several studies have demonstrated the huge fragmentation effect caused by roads on herpetofaunal populations. For instance, in an experiment carried out in six paved roads in Virginia and West Virginia (USA) with translocated individuals of redback salamander 
(Plethodon cinereus) the rate of return for those who had to cross a road was about a $50 \%$ lower than for those who just had to pass through the forest (MARSH et al., 2005). In this species, genetic differences are visible in those populations bisected by a major highway but not in those separated by secondary roads (MARSH et al., 2008).

As expected, road fragmentation does not affect equally to all species. Short-term impact of fragmentation correlates positively with species' dispersal ability, although those species with low dispersal abilities may be equally affected over long time periods (CUSHMAN, 2006). Most frog species in a wooded area showed no rejection to the presence of roads and forest roads, and even some species positively selected areas close to roads at certain stages of development. The opposite happened to urodeles as salamanders, whose populations were bigger in remote areas than in zones close to roads (DEMAYNADIER \& HunTER, 2000). For forest salamanders, the edge effect of forest roads due to reduced moisture and vegetation cover is comparable to recently cleared areas (MARSH \& BECKMAN, 2004). Roads also alter selection patterns of the spawning sites in urodeles, especially in those species with little tolerance to alteration, as CHAMBERS (2008) observed for the Jefferson salamander (Ambystoma jeffersonianum) or the marbled salamander (Ambystoma opacum), whereas the more tolerant eastern newt (Notophthalmus viridescens) suffered less severe alterations of spawning site due to road impacts.

Fire-roads can also act as barriers to herpetofauna movements, although there is important variation among species. CARTHEW et al. (2009) found that for most species of terres- trial fauna in south-eastern South Australia, including the bold-striped cool-skink (Bassiana duperreyi), fire-roads were not an obstacle. However, for the painted spadefoot toad (Neobatrachus pictus) no crosses of the fire-road were detected.

Snake responses to habitat fragmentation by roads can vary substantially depending on the species' ecological and anatomical features, the smaller being generally more reluctant to cross (ANDrEws \& GibBOns, 2005). The massasauga (Sistrurus catenatus) shows a clear rejection to traverse roads. In Manitoba (Canada) the red-sided garter snake (Thamnophis sirtalis parietalis) avoided gravel roads (SHINE et al., 2004). The same results were found for the eastern box turtle (Terrapene carolina) and the western box turtle (Terrapene ornata). If this rejection was heritable, road-kills would decrease over time because those individuals who tended not to cross the roads would be selected, which in turn would increase the degree of isolation between populations (SHEPARD et al., 2008b). The interruption of seasonal migrations caused by roads reduced genetic diversity and increased genetic differentiation in timber rattlesnakes (Crotalus horridus), even in a short period of time (CLARK et al., 2010).

Some species can use roads as corridors (Fig. 1). To move between favorable habitats, green frogs (Lithobates clamitans) frequently used, with high survival rates, road drainage ditches inside a matrix of peat fields where they rarely ventured (MAZEROLLE, 2004b). Furthermore, road ditches are suitable insolation areas in forested ecosystems. Roads can also constitute a route of access to habitats with high vegetation cover for termophile species (HEDEEN \& HedEEN, 1999). 
However, the fact that roads can act as corridors may also have negative effects because, similarly, they may favour the spread of invasive species. Road surroundings are habitats with a substantial level of alteration that are favourable to invasive species. For example, the progressive spread of $R$. marina in Australia has been especially fast in areas with high road density and high connectivity (URBAN et al., 2008), which is an expected outcome considering that this invasive toad is more abundant in the roads or tracks than in the surrounding habitats (SEABROOK \& DetTMan, 1996).

\section{Effects of roads on herpetofauna populations}

A good review of the effects of roads on herpetofauna abundance (and also for the rest of the vertebrate groups) can be found in FAHRIG \& RYTWINSKI (2009). They found in the literature 22 amphibians and six reptiles for which road effects had been evaluated. The responses were negative for more than $70 \%$ of amphibians and $80 \%$ of reptiles, although the results were sometimes contradictory. Population declines of herpetofauna species have been attributed, at least partially, to road mortality (FAHRIG et al., 1995; GibBS \& SHRIVER, 2002, 2005; Marchand \& Litvaitis, 2004; Puky, 2006). FAHRIG et al. (1995) or SUTHERLAND et al. (2010) showed that amphibian density was lower in roads with high traffic volumes than in roads with little traffic. Moreover, the ratio between dead and alive individuals was higher as traffic intensity increased. This fact supports the hypothesis that roadkills can cause the decline of amphibian populations near roads, especially in those roads with high traffic volumes. These studies were carried out with anurans but the results are similar for urodeles (SEMLITSCH $e t$ al., 2007). Mortality rates can be higher in new roads and tend to diminish through the time, which would be related to the fact that road-kills contribute to progressively decrease population size, thus causing population declines (CARretero \& Rosell, 2000). In general, amphibian species richness decreases in presence of roads (FINDLAY \& HOUlAHAN, 1997; GARRIGA et al., 2012). It was estimated for $A$. maculatum in several breeding pools in New York State that under the average displacement performed during migration to breeding sites, one to threequarters of the population could be affected by road mortality. In those populations, road-kills involved the addition of more than $10 \%$ to natural mortality, which would jeopardize their long-term viability (GIBBS $\&$ SHRIVER, 2005).

Thresholds of both road density and traffic volume over which the implementation of mitigation measures is justified can be defined using life tables and migration distances of each species (GibBS \& Shriver, 2005). However, differences in behaviour may make some species more susceptible than others to road impact. Thus, the level of vulnerability depends on the mobility of each species. A research carried out in the Ottawa-Carleton region (Ontario, Canada) revealed that, while a mobile species like L. pipiens showed a negative correlation between their population abundances and traffic density on nearby roads, in another species with shorter displacements like $L$. clamitans there was no relationship between population size and traffic intensity (CARR \& FAHRIG, 2001). 
Reptile populations are also vulnerable to roads impacts. A study in Ontario, Canada, with radio-marked individuals of eastern rat snake (Pantherophis obsoletus) showed that the species did not avoid the road and, although the probability of collision was low (less than $1 \%$ ), mortality was big enough to compromise the long-term population viability (Row et al., 2007). For snakes, mobility is also a key factor to explain the inter-specific differences found in population vulnerability to road impacts (BONNET et al., 1999). Thus, forager snakes show higher vulnerability to roads than sedentary ones (MEEK, 2009). A model including road network, traffic volume and mobility of two species estimated an annual road mortality rate about three times higher for mobile species than for sedentary ones (14-21\% for the plain-bellied watersnake, Nerodia erythrogaster, vs. 3-5\% in the Lake Erie water snake, Nerodia sipedon) (RoE et al., 2006).

It is necessary to point out that road mortality can affect populations as long as these populations are limited by mechanisms independent from population density, in which case road-kills have an additive effect. Moreover, the distribution of casualties in relation to sex and age is also very important to assess the real impact of road-kills. For example, the mortality of females of oviparous species on their egg-laying migrations is likely to be more damaging to population viability than the same mortality rate affecting males or neonates (BONNET et al., 1999). These sex- or agerelated differences in magnitude of road impacts can modify the demographic structure of herpetofauna populations. In northern Portugal, males of Lataste's viper (Vipera latastei) and Seoane's viper (Vipera seoanei) were more frequently found road-killed than females, and the same happened to adults relative to immature individuals. Moreover, a peak in the number of road-kills was found during the spring (BRito \& Álvares, 2004), and the same happened for populations of those two species in northern Spain (MARTínEZ-FreIRÍA \& BRITO, 2012). On the other hand, MONTORI et al. (2003) suggested that for most snake species in Catalonia, including the horseshoe whip snake (Hemorrhois hippocrepis), the Montpellier snake (Malpolon monspessulanus), the ladder snake (Rhinechis scalaris) and the southern smooth snake (Coronella girondica), immature individuals would be more frequently road-killed than adults, being the peak of road mortality coincident with juvenile dispersal in late summer and fall. However, because of the low detectability of small individuals the real impact of road-kills on immature specimens would be underestimated.

Male-biased road mortality has also been reported for other snake species like $S$. catenatus, with a peak at the end of the summer (SHEPARD et al., 2008a), or C. horridus, with males showing a road mortality rate 13 times higher than females (ALDRIDGE \& BROWN, 1995). This bias could be explained by the high mobility of males, especially during the mating season when they increase their movements in search of females. Common green iguana (Iguana iguana) males suffer more road-kills than females, and populations near roads show a female-biased sex ratio of the adult population (RODDA, 1990). For certain freshwater turtle species, roadkills constitute a serious threat for their populations (GiBBS \& SHRIVER, 2002). A welldocumented phenomenon in these species is the disproportionately high number of females road-killed during their displacements to 
overland nesting locations, an effect that is not so pronounced in semi-aquatic and terrestrial turtles. As a result, freshwater turtle populations near roads are biased towards males (STEEN \& GiBBS, 2004; STEEN et al., 2006) and this bias has increased linearly during last decades (GIBbs \& STEEN, 2005). Moreover, the edges of the road may become attractive places to establish nests, which attracts females to the vicinity of the road (AREsCO, 2005a). Thus, in many aquatic turtles the nesting period coincides with the maximum rate of road-kills (BEAUDRY et al., 2010). On the contrary, for other species like the diamondback terrapin (Malaclemys terrapin) there is no relationship between the proximity to roads and variations in individual density or sex ratio (GROSSE et al., 2011).

Road impacts do not act only at a local scale. On a regional scale, the presence of roads is one of the main elements that explain the presence of various species of salamanders, but with different results depending on the specific tolerance to altered environments: the tolerant species are benefited while the abundance of the sensitive ones decreases (WARD et al., 2008). Road density is negatively correlated to the presence of $R$. arvalis whose probability of occurrence in habitats adjacent to roads is halved compared to what happens in non-fragmented areas. This fact shows that habitat fragmentation is one of the factors that explain the species' spatial distribution patterns (VOS \& CHARDON, 1998). The viability of a common spadefoot (Pelobates fuscus) metapopulation isolated by roads is quickly compromised by a slight decrease of individuals dispersing from source populations (HELS \& NACHMAN, 2002). In fact, the magnitude of the impact of the road network on forest anurans can be as high as the impact of habitat loss, as demonstrated by EIGENBROD et al. (2008), who observed in Ontario (Canada) that the species richness and abundance of three of the six species studied were more correlated to traffic density than to the absence of forest.

As a consequence of the fragmentation caused by linear infrastructures there is a reduction in genetic exchange (Vos et al., 2001). Fragmented populations are very vulnerable to inbreeding processes. Low heterozygosity values were found in agile frog (Rana dalmatina) populations living in ponds near roads. The likely cause of this genetic homogenization is the reduction of the number of adult individuals, either by road-kills, noise or pollution (LESBARRÈrES et al., 2003). Beyond lower allelic richness, populations fragmented by roads have a higher degree of genetic differentiation than populations from non-fragmented habitats (LESBARRÈRES et al., 2006).

\section{Road-effect zone for herpetofauna}

The combined effect of all road impacts on herpetofauna populations delimits a "road-effect zone" (Fig. 1) that can be defined as the area in which ecological effects extend outward from a road (FORMAN \& AlEXANDER, 1998). In the Galapagos Islands, lava lizards (Microlophus albemarlensis) have a lower density in the upper $100 \mathrm{~m}$ from the road edge, and show a probability of having experienced tail loss up to 30 times higher than individuals from other populations (TANner \& PERry, 2007). The effect on the Tenerife lizard (Gallotia galloti) varies in relation to the adjacent habitat; while roads can play their usual role as barriers or source of 
mortality, in those cases where roads cross habitats unsuitable for the species, like the laurel forest, they may act as corridors (Delgado García et al., 2007). Lungless salamanders avoid even the forest roads created for the timber industry, especially the oldest ones, within a band of about $35 \mathrm{~m}$ (SEMlitsch et al., 2007). BOARMAN \& SAZAKI (2006) found that the population density of desert tortoises (Gopherus agassizii) increased with the distance to the road edge, being especially small within a band of about $800 \mathrm{~m}$ around the road. VON SECKENDORFF HofF \& MARLOW (2002) extended this road-effect zone to a $4000 \mathrm{~m}$ bandwidth.

The decrease in population density may not have linear relationship with the distance to the road and it is possible to detect thresholds; for example, EIGENBROD et al. (2009) identified in Ontario a threshold in population abundance at 250-1000 $\mathrm{m}$ from road edge for more than half of the studied species, as well as for the species richness itself. Finally, off-road vehicles may add an adverse effect on populations inhabiting road proximities (BURY \& LUCKENBACH, 2002).

\section{Mitigation measures to reduce road impacts on berpetofauna}

Various mitigation measures with different efficacies and costs have been proposed in order to solve, or at least reduce the impact of road-kills and habitat fragmentation on amphibians and reptiles. The construction of fences or walls that impede access to the road has been effective in reducing mortality of amphibians (RYSER \& GrossENBACHER, 1989; DODD et al., 2004). The installation of a temporary fence reduced the mortality in freshwater turtles by more than 99\%, effectively preventing the crossing attempts, which had only a $2 \%$ of chance of success (ARESCO, 2005b). However, although the installation of fences decreases the mortality rate due to collisions, it also reduces the connectivity with the other side of the road, making the migration to breeding sites difficult and enhancing population isolation.

In order to promote habitat defragmentation, the adaptation of drainages and the construction of wildlife crossings designed for herpetofauna have been proposed. The effectiveness of this measure is supported by the fact that amphibian migration is facilitated by tunnels constructed for drainage under roads (HARTEL et al., 2009). The design and construction features that increase the effectiveness of herpetofauna passages vary among species, although there is considerable flexibility that facilitates decision-making to find a compromise considering the species present in the area. Woltz et al. (2008) found that all the studied species - two freshwater turtles, C. serpentina and the painted turtle (Chrysemys picta), and two anurans (L. clamitans and L. pipiens) - preferred tunnels with diameter widths above $50 \mathrm{~cm}$ and sand or gravel firm, together with a fence of about $60 \mathrm{~cm}$. The species showed a strong dislike for structures with diameters below 30 $\mathrm{cm}$. In this sense, longer tunnels require larger diameters (PUKY, 2003). LESBARRÈRES et al. (2004) found that while B. bufo and the edible frog (Pelophylax esculentus) used the tunnels, $R$. dalmatina rejected them. All species preferred soil beds rather than bare concrete and corrugated steel. A viaduct construction together with the installation of a fence designed for amphibians and reptiles drastically reduced mortality in a road that run between two 
wetlands (SCOCCIANTI, 2006). The accessibility must be guaranteed in order to keep the tunnels or other kind of herpetofauna crossings functional (PUKY, 2003).

The location of herpetofauna passages should be selected following the knowledge acquired in the studies about the spatio-temporal distribution of road-kills as well as about the herpetofauna use of the space (PATRICK et al., 2010). Decision-making must take into account those routes positively selected by animals and the amplitude of their movement ranges (VAN GELDER et al., 1986; HARTEL et al., 2009). Several methodologies have been used to quantify the effectiveness of the mitigation measures: track plates (not specific for herpetofauna) (e.g. MATA et al., 2005), funnel traps or pitfall traps at tunnel exits (DoDD et al., 2004) or cameras to monitor tunnel use (PAGNUCCO et al., 2011).

Additionally, the structures associated with main roads, like ditches for drainage of rain water, seemingly harmless, can become real traps for amphibians during their migration. ZHANG et al. (2010) described this problem for juveniles and sub-adults of Asian common toad (Duttaphrynus melanostictus). A design with sloping side walls with a maximum tilt of $66^{\circ}$, with a firm edge of stone and gravel with a cement grout and vegetation would minimize the impact of these structures on amphibian populations.

Another suggested measure to reduce road impacts on fauna is the maintenance of clear, unvegetated margins to allow drivers for seeing animals before they begin to cross the road (Rosell \& Velasco, 1999). While this is a measure basically though for large mammals, it can indirectly benefit reptiles; especially in forested areas, clear margins would constitute an area of insolation, out of the zone of collision risk, for most reptiles that tend to use roads for thermoregulation.

During road construction, habitat destruction can affect negatively to herpetofauna populations. GUYOT \& ClOBERT (1997) proposed to minimize the impact on a population of Hermann's tortoise (Testudo hermanni) by means of capturing and maintaining them in fenced spaces during construction of the road, and then releasing them after completion of the works. It has also been proposed that, when aquatic habitats used by amphibians for breeding are eliminated as part of the road construction process, the creation of replacement ponds close to where the destroyed ones were located would minimize the impact for populations (LESBARRÈRES et al., 2010).

Cost-benefit analysis is a possible approach to facilitate decision-making about where to locate mitigation measures. This approach follows economic criteria and tends to maximize the return in measure investments. SHWIFF et al. (2007), following the principles of ecological economics, quantified the economic losses associated with the herpetofauna road-kills in a Florida wilderness. Contrarily to these estimations including, for example, large ungulates, where it is possible to assess vehicle or human damages related to collisions, in the case of herpetofauna the authors selected the penalty that would be imposed by law in the state of Florida for the collection of an individual of the species found killed on roads in order to calculate the economic value of the losses.

Most mitigation measures are usually thought and designed for their implementation at a local scale, following the recommendations of the environmental impact assess- 
ments. However, this scale fails to ensure adequate consideration of the potentially serious cumulative, indirect and synergistic ecological effects of roads. An adequate plan to minimize road impacts should start at the regional scale by spatial planning and strategic environmental assessment of the road network (TREWEEK et al., 1998), including the conservation of the herpetofauna species as another goal to achieve. For example, certain species such as the common snake-necked turtle (Chelodina longicollis) use different types of water points as a function of hydroperiods and seasonal movements. Therefore, their conservation requires not only the protection of water points and a land area around them, but should consider the diversity of habitats they use and ensure connectivity between them (RoE \& GEORGES, 2007). The first step could be the identification of areas with high herpetofauna diversity. These would be the priority areas to install mitigation measures in the existing roads, and at the same time, they would be the areas protected from new infrastructure projects (BENAYAS et al., 2006). The same treatment should be applied to protected areas, where road-kill rates can be elevated due to the reception of visitors (GARRIGA et al., 2012).

\section{CONCLUSION}

According to the results of dozens of studies about the relationship between herpetofauna and roads, the increasing vehicular traffic is widely suspected to compromise herpetofauna conservation and to play a role in population declines. Nevertheless, the research about the road impacts on the herpetofauna is fragmented, limited for comparisons among zones, with methodological problems, and inconclusive (ELZANOWSKI et al., 2009). Moreover, research results may sometimes be unexpected. For example, highway water ponds may surprisingly contribute to increase amphibian biodiversity in altered landscapes (LE VIOL et al., 2012). As we stated, the results of the road effects on herpetofauna populations can be contradictory (see FAHRIG \& RYTWINSKI, 2009). We should deepen in the origins of these contradictions and the role that the differences in methodology play on them. An important effort to integrate all the information available is required.

To increase our understanding about this topic we should exploit any technique or methodology available. Particularly promising are the advances in genetic analyses that allow the detection of small differences between populations that have partially lost their connectivity. At this respect, genetic results reveal that traffic intensity reduction could be a good solution for certain species (e.g. the palmate newt, Lissotriton helveticus) but not for others for which even the secondary roads with low traffic volumes act as barriers (e.g. the common midwife toad, Alytes obstetricans) (GARCIA-GonZALEZ et al., 2012). Therefore, DNA analysis becomes a powerful tool to facilitate road planners and environmental managers the decision-making about the most effective mitigation measures. This decision is not always easy since the species present can respond differently to the same mitigation measure. Moreover, population consequences also vary among species both quantitatively and qualitatively. In this context it becomes necessary to develop mechanisms to reach a consensus solution.

Road effects have been quantified only for a few number of herpetofauna species. More research on unstudied species and in different 
habitats is required, especially in those areas comprising both high biodiversity levels and an increasing expansion of the road networks (e.g. rainforests, Hoskin \& GoOSEM, 2010). Moreover, other possible road effects or mechanisms of affection should be considered. Thus, the loss of older individuals by road-related mortality could lead long-lived species to a depression in population reproduction rates (KARRAKER \& GIBBS, 2011).

Much more effort should focus on the increase of public awareness about this conservation issue. Indirect impacts of roads are not visible and, unlike with large mammals, direct effects such as road mortality on herpetofauna often go unnoticed for the society. It is necessary to help people take consciousness of the problem by implementing educational initiatives for transport and spatial planners and designers, drivers, environmental managers, and other people involved in transport and conservation issues, as well as for the public in general. The aim should be to achieve the routine incorporation of mitigation measures at a local scale and an adequate spatial planning to minimize road impacts on herpetofauna populations at a regional scale.

\section{Acknowledgement}

We are grateful to the editors of Basic and Applied Herpetology for giving us the opportunity to publish this review. Special thank to Dr. Manuel E. Ortiz Santaliestra for his collaboration and useful comments. Dr. Albert Montori and another anonymous reviewer contributed to improve the article with their suggestions. This study was partially funded by a predoctoral fellowship by the Junta de Castilla y Leon and the European Social Fund.

\section{REFERENCES}

Aldridge, R.D. \& Brown, W.S. (1995). Male reproductive cycle, age at maturity, and cost of reproduction in the timber rattlesnake (Crotalus horridus). Journal of Herpetology 29: 399-407.

ANDrEWs, K.M. \& GibBOns, J.W. (2005). How do highways influence snake movement? Behavioral responses to roads and vehicles. Copeia 2005: 772-782.

Antworth, R.L.; Pike, D.A. \& Stevens, E.E. (2005). Hit and run: effects of scavenging on estimates of roadkilled vertebrates. Southeastern Naturalist 4: 647-656.

Aresco, M.J. (2005a). The effect of sex-specific terrestrial movements and roads on the sex ratio of freshwater turtles. Biological Conservation 123: 37-44.

Aresco, M.J. (2005b). Mitigation measures to reduce highway mortality of turtles and other herpetofauna at a north Florida lake. Journal of Wildlife Management 69: 549-560.

Ashley, E.P. \& Robinson, J.T. (1996). Road mortality of amphibians, reptiles and other wildlife on the Long Point causeway, Lake Erie, Ontario. Canadian Field Naturalist 110: 403-412.

Ashley, E.P.; Kosloski, A. \& Petrie, S.A. (2007). Incidence of intentional vehiclereptile collisions. Human Dimensions of Wildlife 12: 137-143.

Ballasina, D. (1989). 'Toads on Roads' in Belgium, In T.E.S. Langton (ed.) Amphibians and Roads: Proceedings of the Toad Tunnel Conference, Rendsburg, Federal Republic of Germany, 7-8 January 1989. ACO Polymer Products, Shefford, Bedfordshire, UK, pp. 83-86. 
Beaudry, F.; DeMaynadier, P.G. \& Hunter, JR., M.L. (2008). Identifying road mortality threat at multiple spatial scales for semi-aquatic turtles. Biological Conservation 141: 2550-2563.

Beaudry, F.; DeMaynadier, P.G. \& Hunter, JR., M.L. (2010). Identifying hot moments in road-mortality risk for freshwater turtles. Journal of Wildlife Management 74: 152-159.

Becker, C.G.; Fonseca, C.R.; Haddad, C.F.B.; BATISTA, R.F. \& Prado, P.I. (2007). Habitat split and the global decline of amphibians. Science 318: 1775-1777.

Beckmann, C. \& Shine, R. (2012). Do drivers intentionally target wildlife on roads? Austral Ecology 37: 629-632.

Bee, M.A. \& Swanson, E.M. (2007). Auditory masking of anuran advertisement calls by road traffic noise. Animal Behaviour 74: 1765-1776.

Benayas, J.M.R.; De La Montaña, E.; Belliure, J. \& Eekhout, X.R. (2006). Identifying areas of high herpetofauna diversity that are threatened by planned infrastructure projects in Spain. Journal of Environmental Management 79: 279-289. Bernardino, Jr., F.S. \& Dalrymple, G.H. (1992). Seasonal activity and road mortality of the snakes of the Pa-hay-okee wetlands of Everglades National Park, USA. Biological Conservation 62: 71-75.

Birdsall, C.W.; Grue, C.E. \& Anderson, A. (1986). Lead concentration in bullfrog Rana catesbeiana and green frog R. clamitans tadpoles inhabiting highway drainages. Environmental Pollution Series A, Ecological and Biological 40: 233-247.

Blaustein, A.R. \& Wake, D.B. (1990). Declining amphibian populations: a glo- bal phenomenon? Trends in Ecology and Evolution 5: 203-204.

Boarman, W.I. \& SazaKI, M. (2006). A highway's road-effect zone for desert tortoises (Gopherus agassizii). Journal of Arid Environments 65: 94-101.

Bonnet, X.; Naulleau, G. \& Shine, R. (1999). The dangers of leaving home: dispersal and mortality in snakes. Biological Conservation 89: 39-50.

Bouchard, J.; Ford, A.T.; Eigenbrod, F.E. \& FAHRIG, L. (2009). Behavioral responses of northern leopard frogs (Rana pipiens) to roads and traffic: implications for population persistence. Ecology and Society 14: 23. Brito, J.C. \& Álvares, F.J. (2004). Patterns of road mortality in Vipera lataste $i$ and $V$. seoanei from northern Portugal. Amphibia-Reptilia 25: 459-465.

BRockIE, R.E.; SADLEIR, R.M.F.S. \& LINKLATER, W.L. (2009). Long-term wildlife road-kill counts in New Zealand. New Zealand Journal of Zoology 36: 123-134.

BrZeZIŃsKI, M.; EliAVA, G. \& ŻMIHORSKI, M. (2012). Road mortality of pond-breeding amphibians during spring migrations in the Mazurian Lakeland, NE Poland. European Journal of Wildlife Research 58: 685-693.

BuChanan, B.W. (1993). Effects of enhanced lighting on the behaviour of nocturnal frogs. Animal Behaviour 45: 893-899.

Bugbee, R.E. (1945). A note on the mortality of snakes on highways in western Kansas. Transactions of the Kansas Academy of Science 47: 373-374.

BurY, R.B. \& LuCKenbaCh, R.A. (2002). Comparison of desert tortoise (Gopherus agassizii) populations in an unused and off-road vehicle area in the Mojave 
Desert. Chelonian Conservation and Biology 2: 457-463.

Cairo, S.L. \& Zalba, S.M. (2007). Effects of a paved road on mortality and mobility of red bellied toads (Melanophryniscus sp.) in Argentinean grasslands. AmphibiaReptilia 28: 377-385.

CAMPBelL, H. (1956). Snakes found dead on the roads of New Mexico. Copeia 1956: 124-125.

Carpenter, C.C. \& Delzell, D.E. (1951). Road records as indicators of differential spring migrations of amphibians. Herpetologica 7: 63-64.

CARr, L.W. \& FAHrig, L. (2001). Effect of road traffic on two amphibian species of differing vagility. Conservation Biology 15: 1071-1078.

Carretero, M.A. \& Rosell, C. (2000). Incidencia del atropello de anfibios, reptiles y otros vertebrados en un tramo de carretera de construcción reciente. Boletín de la Asociación Herpetológica Española 11: 39-43.

Carthew, S.M.; Horner, B. \& Jones, K.M.W. (2009). Do utility corridors affect movements of small terrestrial fauna? Wildlife Research 36: 488-495.

Carvalho, F. \& Mira, A. (2011). Comparing annual vertebrate road kills over two time periods, 9 years apart: a case study in Mediterranean farmland. European Journal of Wildlife Research 57: 157-174.

Chambers, D.L. (2008). Logging road effects on breeding-site selection in Notophthalmus viridescens (red-spotted newt) and three ambystomatid salamanders in south-central Pennsylvania. Northeastern Naturalist 15: 123-130.

Clark, R.W.; Brown, W.S.; STECHERT, R. \& ZAMUDIO, K.R. (2010). Roads, interrupted dispersal, and genetic diversity in tim- ber rattlesnakes. Conservation Biology 24: 1059-1069.

Clevenger, A.P. (1999). Road Effects on Wildlife: A Research, Monitoring and Adaptive Mitigation Study. Progress Report 5. Banff National Park, Banff, Alberta, Canada.

Clevenger, A.P.; Chruszcz, B. \& Gunson, K.E. (2003). Spatial patterns and factors influencing small vertebrate fauna roadkill aggregations. Biological Conservation 109: 15-26.

Coelho, I.P.; Teixeira, F.Z.; Colombo, P.; Coelho, A.V.P. \& Kindel, A. (2012). Anuran road-kills neighboring a periurban reserve in the Atlantic Forest, Brazil. Journal of Environmental Management 112: 17-26.

Collins, J.P. \& STORfer, A. (2003). Global amphibian declines: sorting the hypotheses. Diversity and Distributions 9: 89-98.

Collins, S.J. \& Russell, R.W. (2009). Toxicity of road salt to Nova Scotia amphibians. Environmental Pollution 157: 320-324.

COOKE, A.S. (1995). Road mortality of common toads (Bufo bufo) near a breeding site, 1974-1994. Amphibia-Reptilia 16: 87-90.

Cunnington, G.M. \& Fahrig, L. (2010). Plasticity in the vocalizations of anurans in response to traffic noise. Acta Oecologica 36: 463-470.

Cureton, II, J.C. \& Deaton, R. (2012). Hot moments and hot spots: identifying factors explaining temporal and spatial variation in turtle road mortality. Journal of Wildlife Management 76: 1047-1052.

Cushman, S.A. (2006). Effects of habitat loss and fragmentation on amphibians: A review and prospectus. Biological Conservation 128: 231-240. 
Dávila Blanes, A.; Terrones Contreras, B.; Cantó Corchado, J.L. \& Bonet Jornet, A. (2007) Mortalidad de vertebrados por atropello en la carretera CV797 de acceso al santuario de la Font Roja. Años 2000-2006. Iberis 5: 38-52.

Delgado García, J.D.; Arévalo, J.R. \& FERNÁNDEZ-PalaCios, J.M. (2007). Road edge effect on the abundance of the lizard Gallotia galloti (Sauria: Lacertidae) in two Canary Islands forests. Biodiversity and Conservation 16: 2949-2963.

deMaynadier, P.G. \& Hunter, JR., M.L. (2000). Road effects on amphibian movements in a forested landscape. Natural Areas Journal 20: 56-65.

DODD, JR., K.C.; BARICHIVICH, W.J. \& SMITH, L.L. (2004). Effectiveness of a barrier wall and culverts in reducing wildlife mortality on a heavily traveled highway in Florida. Biological Conservation 118: 619-631.

Eigenbrod, F.; Hecnar, S.J. \& Fahrig, L. (2008). The relative effects of road traffic and forest cover on anuran populations. Biological Conservation 141: 35-46.

Eigenbrod, F.; Hecnar, S.J. \& Fahrig, L. (2009). Quantifying the road-effect zone: threshold effects of a motorway on anuran populations in Ontario, Canada. Ecology and Society 14: 24.

Elzanowski, A.; CiesioŁKIEWICZ, J.; KaCZOR, M.; RADWAŃSKa, J. \& URBAN, R. (2009). Amphibian road mortality in Europe: a meta-analysis with new data from Poland. European Journal of Wildlife Research 55: 33-43.

FAHRIG, L. \& RYTWINSKI, T. (2009). Effects of roads on animal abundance: an empirical review and synthesis. Ecology and Society 14: 21.
Fahrig, L.; Pedlar, J.H.; Pope, S.E.; TAYLOR, P.D. \& Wegner, J.F. (1995). Effect of road traffic on amphibian density. Biological Conservation 73: 177-182.

Findlay, C.S. \& Houlahan, J. (1997). Anthropogenic correlates of species richness in southeastern Ontario wetlands. Conservation Biology 11: 1000-1009.

FiTch, H.S. (1949). Road counts of snakes in western Louisiana. Herpetologica 5: 87-90.

Forman, R.T.T. \& AlEXANDER, L.E. (1998). Roads and their major ecological effects. Annual Review of Ecology and Systematics 29: 207-231.

Forman, R.T.T.; SPERling, D.; BisSONETTE, J.A.; Clevenger, A.P.; Cutshall, C.D.; Dale, V.H.; Fahrig, L.; France, R.; Goldman, C.R.; Heanue, K.; Jones, J.A.; Swanson, F.J.; Turrentine, T. \& Winter, T.C. (2003). Road Ecology: Science and Solutions. Island Press, Washington, D.C., USA.

Garcia-Gonzalez, C.; Campo, D.; Pola, I.G. \& Garcia-Vazquez, E. (2012). Rural road networks as barriers to gene flow for amphibians: Species-dependent mitigation by traffic calming. Landscape and Urban Planning 104: 171-180.

Garriga, N.; Santos, X.; Montori, A.; Richter-Boix, A.; Franch, M. \& Llorente, G.A. (2012). Are protected areas truly protected? The impact of road traffic on vertebrate fauna. Biodiversity and Conservation 21: 2761-2774.

Gerow, K.; Kline, N.C.; Swann, D.E. \& POKORNY, M. (2010). Estimating annual vertebrate mortality on roads at Saguaro National Park, Arizona. Human-Wildlife Interactions 4: 283-292. 
Gibbs, J.P. \& Shriver, W.G. (2002). Estimating the effects of road mortality on turtle populations. Conservation Biology 16: 1647-1652.

GibBs, J.P. \& Shriver, W.G. (2005). Can road mortality limit populations of poolbreeding amphibians? Wetlands Ecology and Management 13: 281-289.

GibBs, J.P. \& STEEN, D.A. (2005). Trends in sex ratios of turtles in the United States: implications of road mortality. Conservation Biology 19: 552-556.

Glista, D.J.; DeVault, T.L. \& DeWoody, J.A. (2008). Vertebrate road mortality predominantly impacts amphibians. Herpetological Conservation Biology 3: 77-87.

Goldingay, R.L. \& TAYLOR, B.D. (2006). How many frogs are killed on a road in North-east New South Wales? Australian Zoologist 33: 332-336.

GonZÁleZ-Prieto, S.; Villarino, A. \& FrEÁN, M.M. (1993). Mortalidad de vertebrados por atropello en una carretera nacional del NO de España. Ecología 7: 375-389.

Goodman, S.M.; Pidgeon, M. \& O'Connor, S. (1994). Mass mortality of Madagascar radiated tortoise caused by road construction. Oryx 28: 115-118.

Grant, T.J. \& DOHERTY, JR., P.F. (2009). Potential mortality effects of off-highway vehicles on the flat-tailed horned lizard (Phrynosoma mcallii): a manipulative experiment. Environmental Management 43: 508-513.

Grosse, A.M.; Maerz, J.C.; HepinstallCymerman, J. \& Dorcas, M.E. (2011). Effects of roads and crabbing pressures on diamondback terrapin populations in coastal Georgia. Journal of Wildlife Management 75: 762-770.
GrYZ, J. \& Krauze, D. (2008). Mortality of vertebrates on a road crossing the Biebrza Valley (NE Poland). European Journal of Wildlife Research 54: 709-714.

Gu, H.; DaI, Q.; WanG, Q. \& WanG, Y. (2011). Factors contributing to amphibian road mortality in a wetland. Current Zoology 57: 768-774.

Guyot, G. \& Clobert, J. (1997). Conservation measures for a population of Hermann's tortoise Testudo hermanni in southern France bisected by a major highway. Biological Conservation 79: 251-256.

Hartel, T.; Moga, C.I.; Öllerer, K. \& PUKY, M. (2009). Spatial and temporal distribution of amphibian road mortality with a Rana dalmatina and Bufo bufo predominance along the middle section of the Târnava Mare basin, Romania. North-Western Journal of Zoology 5: 130-141.

Hartmann, P.A.; Hartmann, M.T. \& MARTINS, M. (2011). Snake road mortality in a protected area in the Atlantic forest of southeastern Brazil. South American Journal of Herpetology 6: 35-42. Haxton, T. (2000). Road mortality of snapping turtles, Chelydra serpentina, in central Ontario during their nesting period. Canadian Field-Naturalist 114: 106-110.

Hedeen, S.E. \& HedeEn, D.L. (1999). Railway-aided dispersal of an introduced Podarcis muralis population. Herpetological Review 30: 57-58.

Hels, T. \& Buchwald, E. (2001). The effect of road kills on amphibian populations. Biological Conservation 99: 331-340.

Hels, T. \& Nachman, G. (2002). Simulating viability of a spadefoot toad Pelobates fuscus metapopulation in a 
landscape fragmented by a road. Ecography 25: 730-744.

Hobday, A.J. \& Minstrell, M.L. (2008).

Distribution and abundance of roadkill on

Tasmanian highways: human management options. Wildlife Research 35: 712-726.

Hodson, N.L. (1960). A survey of vertebrate road mortality 1959. Bird Study 7: 224-231. Hoskin, C.J. \& Goosem, M.W. (2010). Road impacts on abundance, call traits, and body size of rainforest frogs in northeast Australia. Ecology and Society 15: 15.

Houlahan, J.E.; Findlay, C.S.; SCHMidT, B.R.; Meyer, A.H. \& KuZMin, S.L. (2000). Quantitative evidence for global amphibian population declines. Nature 404: 752-755.

JAARSMA, C.F.; VAN LANGEVELDE, F. \& Botma, H. (2006). Flattened fauna and mitigation: Traffic victims related to road, traffic, vehicle, and species characteristics. Transportation Research Part D: Transport and Environment 11: 264-276.

Jakob, C.; Poizat, G.; Veith, M.; Seitz, A. \& Crivelli, A.J. (2003). Breeding phenology and larval distribution of amphibians in a Mediterranean pond network with unpredictable hydrology. Hydrobiologia 499: 51-61.

Kaiser, K. \& Hammers, J.L. (2009). The effect of anthropogenic noise on male advertisement call rate in the Neotropical treefrog, Dendropsophus triangulum. Behaviour 146: 1053-1069.

Karraker, N.E. \& GibBs, J.P. (2011). Contrasting road effect signals in reproduction of long- versus short-lived amphibians. Hydrobiologia 664: 213-218.

KARRAKER, N.E.; GibBS, J.P. \& VONESH, J.R. (2008). Impacts of road deicing salt on the demography of vernal pool-breeding amphibians. Ecological Applications 18: 724-734.

Kovar, R.; Brabec, M.; Vita, R. \& BOCEK, R. (2009). Spring migration distances of some Central European amphibian species. Amphibia-Reptilia 30: 367-378.

Langen T.A.; MachniaK, A.; Crowe, E.K.; Mangan, C.; Marker, D.F.; Liddle, N. \& Roden, B. (2007). Methodologies for surveying herpetofauna mortality on rural highways. Journal of Wildlife Management 71: 1361-1368.

Langen, T.A.; Ogden, K.M. \& SCHWARTING, L.L. (2009). Predicting hot spots of herpetofauna road mortality along highway networks. Journal of Wildlife Management 73: 104-114.

Langen, T.A.; Gunson, K.E.; Scheiner, C.A. \& Boulerice, J.T. (2012). Road mortality in freshwater turtles: identifying causes of spatial patterns to optimize road planning and mitigation. Biodiversity and Conservation 21: 3017-3034.

LANGTON, T.E.S. (1989). Reasons for preventing amphibian mortality on roads, In T.E.S. Langton (ed.). Amphibians and Roads: Proceedings of the Toad Tunnel Conference, Rendsburg, Federal Republic of Germany, 7-8 January 1989. ACO Polymer Products, Shefford, Bedfordshire, UK, pp. 75-80.

Le Viol, I.; Chiron, F; Julliard, R. \& Kerbiriou, C. (2012). More amphibians than expected in highway stormwater ponds. Ecological Engineering 47: 146-154.

Lebboroni, M. \& Corti, C. (2006). Road killing of lizards and traffic density in central Italy, In M. Vences, J. Köhler, T. Ziegler \& W. Böhme (eds.) Herpetologia Bonnensis II. Proceedings of the 13th Congress of the 
Societas Europaea Herpetologica. Societas Europaea Herpetologica, Bonn, Germany, pp. 81-82.

Lengagne, T. (2008). Traffic noise affects communication behaviour in a breeding anuran, Hyla arborea. Biological Conservation 141: 2023-2031.

Lesbarrères, D.; Pagano, A. \& Lodé, T. (2003). Inbreeding and road effect zone in a Ranidae: the case of Agile frog, Rana dalmatina Bonaparte, 1840. Comptes Rendus Biologies 326: S68-S72.

Lesbarrères, D.; LODÉ, T. \& MERILÄ, J. (2004). What type of amphibian tunnel could reduce road kills? Oryx 38: 220-223.

Lesbarrères, D.; Primmer, C.R.; Lodé T. \& Merilä, J. (2006). The effects of 20 years of highway presence on the genetic structure of Rana dalmatina populations. Ecoscience 13: 531-538.

Lesbarrères, D.; Fowler, M.S.; Pagano, A. \& LodÉ, T. (2010). Recovery of anuran community diversity following habitat replacement. Journal of Applied Ecology 47: 148-156.

LODÉ, T. (2000). Effect of a motorway on mortality and isolation of wildlife populations. Ambio 29: 163-166.

Malo, J.E.; SuÁrez, F. \& Díez, A. (2004). Can we mitigate animal-vehicle accidents using predictive models? Journal of Applied Ecology 41:701-710.

MarChand, M.N. \& Litvaitis, J.A. (2004). Effects of habitat features and landscape composition on the population structure of a common aquatic turtle in a region undergoing rapid development. Conservation Biology 18: 758-767.

Marsh, D.M. \& BeCKMAN, N.G. (2004). Effects of forest roads on the abundance and activity of terrestrial salamanders. Ecological Applications 14: 1882-1891.

Marsh, D.M.; Milam, G.S.; Gorham, N.P. \& BECKMAN, N.G. (2005). Forest roads as partial barriers to terrestrial salamander movement. Conservation Biology 19: 2004-2008.

Marsh, D.M.; Page, R.B.; Hanlon, T.J.; Corritone, R.; Little, E.C.; Seifert, D.E. \& CABE, P.R. (2008). Effects of roads on patterns of genetic differentiation in redbacked salamanders, Plethodon cinereus. Conservation Genetics 9: 603-613.

Martínez-Freiría, F. \& Brito, J.C. (2012). Quantification of road mortality for amphibians and reptiles in Hoces del Alto Ebro y Rudrón Natural Park in 2005. Basic and Applied Herpetology 26: 33-42.

Mata, C.; Hervás, I.; Herranz, J.; SuÁrez, F. \& MALO, J.E. (2005). Complementary use by vertebrates of crossing structures along a fenced Spanish motorway. Biological Conservation 124: 397-405.

Mazerolle, M.J. (2004a). Amphibian road mortality in response to nightly variations in traffic intensity. Herpetologica 60: 45-53.

Mazerolle, M.J. (2004b). Drainage ditches facilitate frog movements in a hostile landscape. Landscape Ecology 20: 579-590.

Mazerolle, M.J.; Huot, M. \& Gravel, M. (2005). Behavior of amphibians on the road in response to car traffic. Herpetologica 61: 380-388.

MEEK, R. (2009). Patterns of reptile road-kills in the Vendée region of western France. Herpetological Journal 19: 135-142.

Montori, A.; Llorente, G.A.; SAntos, X.; Richter-Boix, À. \& GarrigA, N. (2003). Incidència dels atropellaments sobre l'herpetofauna al Parc del Garraf: eix viari Olivella-Rat-Penat, In $\mathrm{K}$. 
Castells, J Hernández \& J. Melero (coords.) IV Trobada d'Estudiosos del Garraf. Series: Monografies, vol. 37. Diputació de Barcelona, Barcelona, Spain, pp. 107-112.

Nyström, P.; Hansson, J.; MÅnsson, J.; Sundstedt, M.; Reslow, C. \& Broström, A. (2007). A documented amphibian decline over 40 years: possible causes and implications for species recovery. Biological Conservation 138: 399-411.

OrŁOWsKI, G. (2007). Spatial distribution and seasonal pattern in road mortality of the common toad Bufo bufo in an agricultural landscape of south-western Poland. Amphibia-Reptilia 28: 25-31.

OrŁowsKI, G.; CiesIOŁKIEWICZ, J.; KACZOR, M.; RADWAŃSKA, J. \& ŻYWICKA, A. (2008). Species composition and habitat correlates of amphibian roadkills in different landscapes of south-western Poland. Polish Journal of Ecology 56: 659-671.

PagnucCO, K.S.; PAszKOWsKi, C.A. \& SCRIMGEOUR, G.J. (2011). Using cameras to monitor tunnel use by long-toed salamanders (Ambystoma macrodactylum): an informative, cost-efficient technique. Herpetological Conservation and Biology 6: 277-286.

PALIS, J.G. (1994). Rana utricularia (southern leopard frog). Road mortality. Herpetological Review 25: 119.

PARris, K.M.; Velik-Lord, M. \& NorTh, J.M.A. (2009). Frogs call at a higher pitch in traffic noise. Ecology and Society 14: 25.

PATRICK, D.A.; SCHAlK, C.M.; GibBS, J.P. \& Woltz, H.W. (2010). Effective culvert placement and design to facilitate passage of amphibians across roads. Journal of Herpetology 44: 618-626.
PINOWSKI, J. (2005). Roadkills of vertebrates in Venezuela. Revista Brasileira de Zoologia 22: 191-196.

Podloucky, R. (1989). Protection of amphibians on roads - examples and experiences from Lower Saxony, In T.E.S. Langton (ed). Amphibians and Roads: Proceedings of the Toad Tunnel Conference, Rendsburg, Federal Republic of Germany, 7-8 January 1989. ACO Polymer Products, Shefford, Bedfordshire, UK, pp. 15-28.

Puky, M. (2003). Amphibian mitigation measures in Central-Europe, In C.L. Irwin, P. Garrett \& K.P. McDermott (eds.) 2003 Proceedings of the International Conference on Ecology and Transportation. Center for Transportation and the Environment, North Carolina State University, Raleigh, North Carolina, USA, pp. 413-429.

PUKY, M. (2006). Amphibian road kills: a global perspective, In C.L. Irwin, P. Garrett \& K.P. McDermott (eds.) Proceedings of the 2005 International Conference on Ecology and Transportation. Center for Transportation and the Environment, North Carolina State University, Raleigh, North Carolina, USA, pp. 325-338.

QUINTERO-ÁNGEL, A.; OSORIODOMingueZ, D.; VARgas-Salinas, F. \& SAAVEDRA-RodrígueZ, C.A. (2012). Roadkill rate of snakes in a disturbed landscape of Central Andes of Colombia. Herpetology Notes 5: 99-105.

Ray, J.E.; Preston, D. \& McCallum, M.L. (2006). Bufo nebulifer (coastal plains toad). Urban road mortality. Herpetological Review 37: 442.

ReEves, M.K.; DolPh, C.L.; ZiMmer, H.; TJeErdema, R.S. \& Trust, K.A. (2008). Road proximity increases risk of skeletal 
abnormalities in wood frogs from National Wildlife Refuges in Alaska. Environmental Health Perspectives 116: 1009-1014.

RodDA, G.H. (1990). Highway madness revisited: roadkilled Iguana iguana in the Llanos of Venezuela. Journal of Herpetology 24: 209-211.

Roe, J.H. \& Georges, A. (2007). Heterogeneous wetland complexes, buffer zones, and travel corridors: Landscape management for freshwater reptiles. Biological Conservation 135: 67-76.

Roe, J.H.; Gibson, J. \& Kingsbury, B.A. (2006). Beyond the wetland border: Estimating the impact of roads for two species of water snakes. Biological Conservation 130: 161-168.

Rosen, P.C. \& Lowe, C.H. (1994). Highway mortality of snakes in the Sonoran desert of southern Arizona. Biological Conservation 68: 143-148.

Rosell, C. \& Velasco, J.M. (1999). Manual de Prevenció $i$ Correcció dels Impactes de les Infraestructures Viàries sobre la Fauna. Entitat Autònoma del Diari Oficial i de Publicacions, Generalitat de Catalunya, Barcelona, Spain.

Row, J.R.; Blouin-DEMERS, G. \& WEATHERHEAD, P.J. (2007). Demographic effects of road mortality in black ratsnakes (Elaphe obsoleta). Biological Conservation 137: 117-124.

Ryser, J. \& Grossenbacher, K. (1989). A survey of amphibian preservation at roads in Switzerland, In T.E.S. Langton (ed) Amphibian ans Roads: Proceedings of the Toad Tunnel Conference, Rendsburg, Federal Republic of Germany, 7-8 January 1989. ACO Polymer Products, Shefford, Bedfordshire, UK, pp. 7-13.
Santos, S.M.; Carvalho, F. \& Mira, A. (2011). How long do the dead survive on the road? Carcass persistence probability and implications for road-kill monitoring surveys. PLoS ONE 6: e25383.

Santos, X.; Llorente, G.A.; Montori, A.; Carretero, M.A.; Franch, M.; Garriga, N. \& Richter-Boix, A. (2007). Evaluating factors affecting amphibian mortality on roads: the case of the Common Toad Bufo bufo, near a breeding place. Animal Biodiversity and Conservation 30: 97-104.

SANZO, D. \& HECNAR, S.J. (2006). Effects of road de-icing salt $(\mathrm{NaCl})$ on larval wood frogs (Rana sylvatica). Environmental Pollution 140: 247-256.

ScOCCIANTI, C. (2006). Rehabilitation of habitat connectivity between two important marsh areas divided by a major road with heavy traffic. Acta Herpetologica 1: 77-79.

SCV (2003). Una Población de Sapo Común y Corredor Está Seriamente Amenazada en el Valle de Lozoya (Madrid). Sociedad para la Conservación de los Vertebrados, Leganés, Madrid, Spain. Available at http://scv-conservacion.webcindario.com/ atropelloslozoya/atropelloslozoya.html. Retrieved on $07 / 19 / 2012$.

Seabrook, W.A. \& Dettmann, E.B. (1996). Roads as activity corridors for cane toads in Australia. Journal of Wildlife Management 60: 363-368.

Semlitsch, R.D.; Ryan, T.J.; Hamed, K.; Chatfield, M.; Drehman, B.; Pekarek, N.; Spath, M. \& Watland, A. (2007). Salamander abundance along road edges and within abandoned logging roads in Appalachian forests. Conservation Biology 21: 159-167. 
Seshadri, K.S.; Yadav, A. \& Gururaja, K.V. (2009). Road kills of amphibians in different land use areas from Sharavathi river basin, central Western Ghats, India. Journal of Threatened Taxa 1: 549-552.

Shepard, D.B.; Dreslik, M.J.; Jellen, B.C. \& PHILLIPS, C.A. (2008a). Reptile road mortality around an oasis in the Illinois corn desert with emphasis on the endangered eastern massasauga. Copeia 2008: 350-359.

Shepard, D.B.; KuHNS, A.R.; Dreslik, M.J. \& PHILLIPS, C.A. (2008b). Roads as barriers to animal movement in fragmented landscapes. Animal Conservation 11: 288-296.

Shine, R.; Lemaster, M.; Wall, M.; LANGKILDE, T. \& MASON, R. (2004). Why did the snake cross the road? Effects of roads on movement and location of mates by garter snakes (Thamnophis sirtalis parietalis). Ecology and Society 9: 9.

Shwiff, S.A.; SMith, H.T.; Engeman, R.M.: BARRY, R.M.; ROSSMANITH, R.J. \& Nelson, M. (2007). Bioeconomic analysis of herpetofauna road-kills in a Florida state park. Ecological Economics 64: 181-185.

Sillero, N. (2008). Amphibian mortality levels on Spanish country roads: descriptive and spatial analysis. Amphibia-Reptilia 29: 337-347.

Slater, F.M. (2002). An assessment of wildlife road casualties - the potential discrepancy between numbers counted and numbers killed. Web Ecology 3: 33-42.

SNODGRASS, J.W.; CASEY, R.E.; JOSEPH, D. \& SimON, J.A. (2008). Microcosm investigations of stormwater pond sediment toxicity to embryonic and larval amphibians: Variation in sensitivity among species. Environmental Pollution 154: 291-297.
STEEN, D.A. \& GIBBS, J.P. (2004). Effect of roads on the structure of freshwater turtle populations. Conservation Biology 18: 1143-1148.

Steen, D.A.; Aresco, M.J.; BeIlKe, S.G.; Compton, B.W.; Condon, E.P.; Dodd, Jr., C.K.; Forrester, H.; GibBONS, J.W.; Greene, J.L.; Johnson, G.; Langen, T.A.; Oldham, M.J.; Oxier, D.N.; SAumure, R.A.; SCHUeler, F.W.; SlEEMAN, J.M.; SMITH, L.L.; TUCKER, J.K. \& GibBS, J.P. (2006). Relative vulnerability of female turtles to road mortality. Animal Conservation 9: 269-273.

Sun, J.W.C. \& NARINS, P.M. (2005). Anthropogenic sounds differentially affect amphibian call rate. Biological Conservation 121: 419-427.

Sutherland, R.W.; Dunning, P.R. \& BAKER, W.M. (2010). Amphibian encounter rates on roads with different amounts of traffic and urbanization. Conservation Biology 24: 1626-1635.

TANnER, D. \& PeRrY, J. (2007). Road effects on abundance and fitness of Galápagos lava lizards (Microlophus albemarlensis). Journal of Environmental Management 85: 270-278.

TAYLOR, B.D. \& GOLDINGAY, R.L. (2004). Wildlife road-kills on three major roads in north-eastern New South Wales. Wildlife Research 31: 83-91.

ToK, C.V.; Ayaz, D. \& ÇıçEK, K. (2011). Road mortality of amphibians and reptiles in the Anatolian part of Turkey. Turkish Journal of Zoology 35: 851-857.

Treweek, J.R.; Hankard, P.; Roy, D.B.; ARnold, H. \& Thompson, S. (1998). Scope for strategic ecological assessment of trunk-road development in England with respect to potential impacts on lowland heathland, the Dartford warbler 
(Sylvia undata) and the sand lizard (Lacerta agilis). Journal of Environmental Management 53: 147-163.

TrombulaK, S.C. \& Frissell, C.A. (2000).

Review of ecological effects of roads on terrestrial and aquatic communities. Conservation Biology 14: 18-30.

Urban, M.C.; Phillips, B.L.; Skelly, D.K. \& Shine, R. (2008). A toad more traveled: The heterogeneous invasion dynamics of cane toads in Australia. American Naturalist 171: 134-148.

VAN Gelder, J.J. (1973). A quantitative approach to the mortality resulting from traffic in a population of Bufo bufo L. Oecologia 13: 93-95.

van Gelder, J.J.; Aarts, H.M. \& StaAl, H.J.W.M. (1986). Routes and speed of migrating toads (Bufo bufo L.): a telemetric study. Herpetological Journal 1: 111-114.

VON SECKendorfF Hoff, K. \& Marlow, R.W. (2002). Impacts of vehicle road traffic on desert tortoise populations with consideration of conservation of tortoise habitat in southern Nevada. Chelonian Conservation and Biology 4: 449-456.

Vos, C.C. \& CHARdon, J.P. (1998). Effects of habitat fragmentation and road density on the distribution pattern of the moor frog Rana arvalis. Journal of Applied Ecology 35: 44-56.

Vos, C.C.; Antonisse-de Jong, A.G.; Goedhart, P.W. \& SMUlders, M.J.M. (2001). Genetic similarity as a measure for connectivity between fragmented populations of the moor frog (Rana arvalis). Heredity 86: 598-608.

Ward, R.L.; Anderson, J.T. \& Petty, J.T. (2008). Effects of road crossings on stream and streamside salamanders. Journal of Wildlife Management 72: 760-771.

Woltz, H.W.; GibBs, J.P. \& DuceY, P.K. (2008). Road crossing structures for amphibians and reptiles: Informing design through behavioral analysis. Biological Conservation 141: 2745-2750.

ZHANG, Z.-X.; YANG, H.-J.; YANG, H.-J.; LI, Y.-X. \& WANG, T.-H. (2010). The impact of roadside ditches on juvenile and subadult Bufo melanostictus migration. Ecological Engineering 36: 1242-1250.

ZUIDERWIJK, A. (1989). Amphibian and reptile tunnels in the Netherlands, In T.E.S. Langton (ed.) Amphibians and Roads: Proceedings of the Toad Tunnel Conference, Rendsburg, Federal Republic of Germany, 78 January 1989. ACO Polymer Products, Shefford, Bedfordshire, UK, pp. 67-74. 